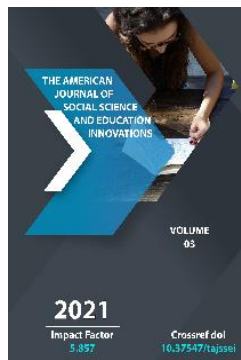

\title{
The Reality Of Life And The Literary Story In Sirojiddin Sayyid's Poem "Eighties"
}

\author{
Rano Makhmudovna Payzullaeva \\ Independent Researcher Of Navoi State Pedagogical Institute, Teacher Of Uzbek Language \\ And Literature At The Academic Lyceum Under Navoi State Mining Institute, Uzbekistan
}

Journal Website:

http://usajournalshub.c om/index,php/tajssei

Copyright: Original content from this work may be used under the terms of the creative commons attributes 4.0 licence.

\section{ABSTRACT}

The article discusses the genre of the epic and its place in the series of genres of epic tours, the issues of the writer's skill in fully expressing the possibilities of the genre, the peculiarities of the plot and compositional structure. It reveals ideological and artistic content of the epic "Eighties" by the poet Sirojiddin Sayyid.

\section{KEYWORDS}

Poem, emotional expression, lyrical pathos, responsibility for the word, word magic, Topolondaryo, philosophical conclusion.

\section{INTRODUCTION}

In an epic play, the scope of artistic representation of reality is wide, and the plot and its parts are in compositional integrity. In prose works, the compositional structure and plot lines of the work are clearly visible. This can also be seen in the epic type of lyric, but still, it is dominated by emotion, and there are significant differences in the location of the 
plot pieces, the compositional structure. Izzat Sultan's book "Literary Theory" describes the genre of the epic as follows:

"As a result of the combination of epic and lyrical features, the epic poem genre is born. The epic poem is actually an epic work, but its poetic form also makes it lyrical. The fact that the epic poem is written in a poetic form reflects not only the character of the form, but also its peculiarity in its content: in the epic, unlike the epic and drama, lyricism acquires a special power" [1, p. 180].

\section{THE MAIN FINDINGS AND RESULTS}

Sirojiddin Sayyid created many epics during his creative career. Each of his three-volume "Works" contains epics written in different years. In particular, the epic "Eighties" is one of the six epics included in the first volume. The plot of the epic consists of the most important political events of the eighties, the struggle for peace, the call to heal the wounds of the earth, the preservation of life on earth, the response to the most painful problems of the time, the expression of the lyrical hero's thoughts, their artistic embodiment. The epic feature of the work is reflected in the coverage of the events of the period, the impact of economic and political crises on the social life of the world through the prism of artistic thinking. The leading image is the lyrical hero in it. He refreshes the reader with his active personality, pain, thoughts, philosophical observations, firm and sharp conclusions, encourages him to think, to think, to feel the pains of the world, the motherland, society, to take serious care of it. Thoughts of sorrow, grief, sorrow, anguish turn into rebellion, the call to awareness, vigilance glorifies vitality, emphasizes the need for self-sacrifice, zeal to heal the wounds of the ground. It is necessary to love life, but it is impossible to achieve it, it is necessary to understand and feel its pain and sorrow, to try to save it from this pain and sorrow.

Hayot!

Ko'zlaringni mendan yashirma!

Hayot!

Dardlarimga o'zing ber hayot!

Sen o'zing dunyoda eng buyuk baxtsan,

Sen o'zing dunyoda eng buyuk faryod [2, p. 276].

Life!

Don't hide your eyes from me!

Life!

Give life to my pains yourself!

You are the greatest happiness in the world, You yourself are the greatest cry in the world.

Emotional expression is the main feature of lyrics. The lyrical protagonist, who glorifies life, describes it as "the greatest happiness," "the greatest cry." The power of emotional perception is reflected in the meaning of the words. The contrast in the words of happiness and cry, the spiritual contradiction expands the field of observation, enhances the effect of emotional expression.

"Kraz" roars in Topolondarya" is now a reality, an expression of the joy of life itself. This joy is manifested in the image of Time and is felt from the heart. The shape of time is Topolondaryo! The mourning of Gissar, which has witnessed the winds, storms and storms of many centuries, and the bliss, such as the Tashkent TV Tower, are beautiful lines to the image of Time. The lyrical protagonist sings aloud that he is more sacred and honorable:

Men-bir oshiq yigit,

Talpinib,

Kecha

Dil anhor bo'yida armonga yetdi. 
Toshkent teleminorasi singari surur

Yuksalib yulduzga, osmonga yetdi.

Foniy hasrat emas-Oliy Orzudan, O'tkinchi g'am emas-Yuksak Ishonchdan,

Tug'yondan,

Vijdondan

giyohdan,

tongdan,

Shabnamdan,

qasamdan,

sevgi,

quvonchdan

Vaqtga haykal qo'ymoq vaqti ham yetdi! [2, pp.

278-279]

I am a young man in love,

Striving,

Yesterday

My heart was in regret by the river.

He stands like a Tashkent TV tower

He ascended to the star, to the sky.

It is not mortal sorrow - from the Supreme

Dream,

Not a temporary grief - From High Confidence,

Hurricane,

From Conscience,

From Cocaine,

From the morning,

From the dew,

From the oath,

From love,

From joy

It's time to put a statue on time!

It is poetic courage, the power of lyrical pathos. The powerful words, the variety of meaning, begin to draw the shape of Time in the reader's eyes. In a small passage one can feel the responsibility of the author of the epic to the word, the skill of word choice, the power of the impact of the power of meaning imposed on the word can be felt. The value and effectiveness of a literary work is determined, first of all, by these factors - the responsibility for the word and its proper use. "Every word chosen must carry a certain burden in a literary work," - says critic Hotam Umurov We determine the significance and power of the story as it unfolds, depending on the authenticity and completeness of the story, the hero's feelings, moods and experiences [3, $\mathrm{p}$. 39].

In the passage above, it is understood that the poet is responsible for the word, the skill of using it in its place; the meaning assigned to each word performs a certain artistic and aesthetic function. Responsibility to the word, its proper use is one of the main features of poetic skill. Poetic images, allusions arise from the magic of words, and the better the creator knows the language, the more he can feel the magic of the word, the more he can create beautiful lyrical landscapes. Literary critic A. Rasulov notes that the word used in its place is the decoration of the poem. "Poetry is the essence of the poet," - he said. Therefore, the creative style is evident in every play. Style is the poet's timeless novelty in seeing, describing, and understanding people. That is, art is a unique style. In poetry, style is felt in symbolism, allegory, and art. There is a poet who observes deeply; there is a poet who shows off the subtlety of words; there is a poet who is immersed in poetry in the world of thought." [4, p. 118]

The epic "Eighties" reflects the qualities, characteristics and requirements of the scientist. The problems of the time, the troubles that afflict humanity, the search for ways to make life more beautiful, the call to overcome the inconsistencies between the universe and man, space and time, are manifested through poetic images created 
with extraordinarily touching metaphors, sharp, percussive, resonant words. The eighties are a symbol of sculpting time. At a time when new life is being wounded in the Topolondarya, when great creativity is taking place, some corners of the earth are full of restless, tumultuous, filthy corruption; human oppression, suffocation of freedom and liberty; yet, before the wounds of war are healed the revenge of those who seek revenge on the world of wealth ignites the fire of wrath in the lyrical protagonist. The unrest in countries like El Salvador, Nicaragua, the death of Muin Bsisu while flying in the sky, the aimless war in Afghanistan are the wounds of the twentieth century. The pain, anguish, the cry, the rage in the poet's aching heart seemed to shake the heart. Because he is telling the truth out loud, even with sharp, sharp words. But the epic is not full of such regrets from the beginning to the end. It inspires confidence in the celebration of optimism, kindness and goodness in every line:

Onajon!

Yorug' duoyingiz dilga jo etdim.

Sizning ko'zyoshlarni o'ylabon,

Bugun

Dunyo ko'zyoshlarin fahmiga yetdim.

Lahzalar!

Lahzalar!

Har biri qalbga

Hududsiz hodisot baxsh etib ketdi.

Yigirmanchi asr hozir tugaydi!

Vaqtga haykal qo'ymoq payti ham yetdi! [5, p.

292]

Mother!

I put your light prayer into my heart.

Thinking of your tears,

Today

I understood the crying of the world.

Moments!
Moments!

Each one to the heart

Was rewarding the boundless event.

The twentieth century is over now!

It's time to put a statue on time!

\section{CONCLUSION}

The epic concludes with the philosophical conclusion, "Time stands before me only - Time in the form of all humanity." Once a work is created, it is very difficult to publish it in a magazine. As in that time those digging dirt on him accuse the author of idealess. However, Erkin Vahidov, who was the editor of "Yoshlik" magazine at the time, published the work in the magazine. The author of the epic, who is grateful for the poet's discipleship, remembers this event with special respect in the chapter "Mercy and Poetry" of the essay "The First Word". He humbly says the following about the epic:

"As for the epic, it was not about the system, but about the time and the state of the world. In it, war was condemned, and I tried to express peace and humanity, man and time, as a precious power, as I imagined, as I understood. Many lines, empty and fleeting phrases can be removed and taken more seriously, leaving a more coherent piece of poetry." [2, p. 442]

\section{REFERENCES}

1. Sultanov Izzat (2005). Literary Theory, Textbook, Revised and supplemented third edition, - Tashkent: "Teacher" Publishing House, p.18o. (Султонов Иззат, Адабиёт назарияси, дарслик, Қайта ишланган ва тўлдирилган учинчи нашри, 
“Ўқитувчи" нашриёт-матбаа ижодий уйи, Тошкент, 2005 й. Б.180.)

2. Sayyid Sirojiddin (2018). Works, Poems, epics, in prose tones. Vol. 1,- Tashkent: "SHARQ" Publishing and Printing JointStock Company General Editorial Office, pp.276, 292, 442. (Саййид Сирожиддин, Асарлар, I жилд, Шеърлар, достонлар, насрий охангларда, "SHARQ” нашриётматбаа акциядорлик компанияси Бош тахририяти, Тошкент, 2018 й. Б.276.)

3. Umurov Hotam (2001), Fundamentals of Art. Tashkent, Uzbekistan, p.39. (Умуров Хотам, Бадиий ижод асослари, Тошкент, “Ўзбекистон”, 2001 й. Б.39.)

4. Rasulov Abdugafur (2007). Artistic novelty, Scientific and literary articles, interpretations, etudes - Tashkent: General Editorial Board of "SHARQ" Publishing and Printing Joint-Stock Company, p. 118. (Расулов Абдуғафур, Бадиийлик-безавол янгилик, Илмийадабий мақолалар, талқинлар, этюдлар, “ШАРқ” нашриёт-матбаа акциядорлик компанияси Бош тахририяти, Тошкент, 2007 й. Б. 118.) 